\title{
Broadening, Deepening, and Governing Innovation: Flemish Technology Assessment in Historical and Socio-Political Perspective
}

Michiel van Oudheusden, Nathan Charlier, Benedikt Rosskamp, Pierre Delvenne

\begin{abstract}
This article examines the socio-political dynamics in the evolution and development of Flemish technology assessment (TA). Broadly defined, TA encompasses activities and programs that expand and deepen the knowledge base of contemporary knowledge-based economies (KBEs), typically by including new actors (e.g. trade unions), ideas (e.g. science in society), and rationales (e.g. participatory techniques) in science, technology, and innovation (STI) processes. Starting from the regionalization of STI policy in Belgium and the convergence of Flemish STI around global KBE principles, the article exemplifies how since the 1980s successive Flemish TA waves (early-warning, bottom-up, and interactive TA) have co-evolved with successive generations of Flemish innovation policy. Building on these findings, it argues that Flemish TA has counteracted and accommodated dominant STI paradigms. By providing a historical and socio-political perspective on TA and innovation policy, the article draws critical attention to the institutional settings and societal contexts in which TA is embedded, and questions TA's strategic utility within contemporary KBEs. This perspective sheds light on the Flemish government's recent decision to close its parliamentary TA institute and the institutional expansion of TA elsewhere in Europe.
\end{abstract}

Keywords: Flanders; Knowledge-based Economy; Innovation Policy; Political Governance; Technology Assessment.

\section{Introduction}

In Flanders, Belgium, government officials, business and industry leaders, academics, and journalists frequently unveil to one another their views on how to spur innovation for economic growth and ensure quality of life. Hence, in a 2006 government-sanctioned report entitled Innovative Flanders: Innovation Policies for the 21st Century, we read that Flanders must ensure "innovation-led growth," as the welfare and wellbeing of the Flemish people depend on hightechnological innovation in the wake of "globalization." In their contribution to the report, the then Flemish Minister of Innovation and members of her ministry call for more collaboration and learning among government, industries, and universities, if Flanders is to remain a "leading innovation region" (CCIP, 2008, p.13; pp.17-18). 
More formally, in 2009 Flemish social partners and captains of industry signed the Pact 2020, indicating a joint resolve to turn Flanders into one of the five top regions in Europe and one of the world's most competitive economies by $2020 .{ }^{1}$ To this end, the Pact outlines a number of domains in which progress is to be made and through which "researchers, companies, and the authorities must work very closely together" within a framework of "open innovation." Accordingly, new, collaborative approaches are to be devised, including ones that sustain the "knowledge commons" on which innovation depends. ${ }^{2}$

To a considerable degree, the visions above advance a strategic-economic rationale to innovation, as they sustain the understanding that innovation is a must to the creation of wellpaying jobs, securing social welfare, and strengthening capacities for international competition and global growth. This outlook is not new. Innovation has long been identified in the social sciences as a major source of economic and social development (e.g. Schumpeter, 1939; Kondratiev, 1978). It also resonates with views voiced elsewhere in the industrialized world. To give an example, the Organization for Economic Cooperation and Development (OECD, 2010) describes innovation as the chief engine of productivity that holds the prospect of supporting economic growth on the cheap, particularly in a time of slow economic development, global warming, and rising prices for natural resources.

In short, innovation and innovation management feature prominently on the public agenda in Flanders, as they do elsewhere, and often within a prevalent market-oriented, knowledgebased economy (KBE) narrative. Following Wullweber (2008), this narrative simultaneously underlines the cooperative pooling of strategic resources and the competitive production of new knowledge as a means of garnering wealth and new employment in industrialized countries. However, the prevalent language of innovation-led growth is also extended in ways that suggest a more comprehensive reading of innovation beyond purely economic and commercial interests. Flemish innovation industries, policymakers, and academics increasingly acknowledge the importance of integrating ecological and social concerns into research and development (R\&D) and business processes if technological innovation is to succeed. In fact, the aim of broadening innovation to include "its non-technological aspects" is now explicitly on the agenda of industry players and the Flemish government as a whole (Vervliet, 2006, p.19). Correspondingly, contemporary science policy discourse is laden with notions such as horizontal governance, open innovation, and social innovation, which stress not only strategic cooperation between multiple actors, including stakeholders and publics, but also the coevolution of technology and society (Felin \& Zenger, 2013). As stated in the Flemish government's 2006 action program Flanders in Action (VIA), Flanders has "great need for a competitive economy, not only to face and tackle the challenges confronting us today and tomorrow, but also to be able to accomplish our goal of creating an open, caring, concerned, and sustainable social environment... there can be neither room nor patience for poverty, social inequality, or exclusion." Thus, social and ecological concerns have entered the policy lexicon,

\footnotetext{
${ }^{1}$ The term "social partners" encompasses employers' organizations and trade unions, who regularly convene to negotiate and reconcile their interests.

${ }^{2}$ See http://www.vlaandereninactie.be/over/over-via.
} 
as has the question of how to incorporate such concerns into innovation strategies. Innovation then, is not only about ensuring international competitiveness through knowledge networking and management, but also about meeting the needs of citizens, and organizing interaction among a larger variety of technological and social actors than has thus far been the case. As these actors include Flemish and European "stakeholders" and citizens, who operate within the framework of an open and inclusive European economy, the VIA program aligns with a broader set of initiatives, such as the 2000 Lisbon Agenda and the more recently established EU Research and Innovation program, Horizon 2020. ${ }^{3}$

Taking these extensions of mainstream STI discourses as its entry point, this article examines how Flemish STI is affected by, and potentially transformed through, technology assessments (TAs). Broadly defined, TA encompasses activities and programs that extend and deepen the knowledge base of contemporary KBEs, typically by including new actors (e.g. trade unions), ideas (e.g. science in society), and rationales (e.g. participatory techniques) in STI processes. Research on TA suggests that the role of TA in national, transnational, and international innovation processes can be substantial (Joss \& Belluci, 2002; Delvenne, 2011; Rodmeyer et al., 2005; Ganzevles et al., 2014). Even if particular TA activities do not directly impact on innovation policy, TA can catalyze democratic debate on technology, raise public awareness about sociotechnical issues, or simply bring together actors and their issues in original ways (Ely et al., 2014; Hennen, 1999; Bütschi \& Nentwich, 2002, p.245). As we show in this article, from the 1980s onwards Flemish TA initiatives challenged technology-centric, market-led innovation policies for failing to consider the wider social, ecological, and ethical ramifications of technology. Shortly after the first Flemish government was installed, policy actors instigated TA programs in an attempt to alleviate the social, economic, and legal consequences of new technologies like biotechnology. These programs emerged in response to pressure from the trade unions, among others, who demanded that R\&D agents take into concern workers' safety and wellbeing. In more recent years, interactive TA forms have developed involving civil society organizations and lay publics, with the aim of formulating social and environmental needs as a starting point for R\&D. Hence, the enlargement of innovation terms and rationales in Flemish STI policies can partly be traced back to TA interventions in Flemish workspaces, governing bodies (e.g. Flemish parliament), and industrial R\&D processes. These spaces in turn provided a fertile basis for the further development of TA and its institutional uptake, as Flemish TA evolved with, and ongoingly drew inspiration from, TA processes elsewhere, including constructive TA (Schot \& Rip, 1997), parliamentary TA (Decker \& Ladikas, 2004; Ganzevles \& Van Est, 2012), and participatory TA (Joss \& Belucci, 2002). Flemish TA can hence be seen as an instructive "test case" for how various kinds of TA mingled with innovation policies and practices within the confines of a high-technology, innovation-driven KBE.

To put the above considerations in due empirical and historical perspective, we retrace the emergence and evolution of Flemish TA in connection to Flemish and European innovation policy (part 2). Our description draws on documentary analysis and on accounts provided to us by policy analysts and spokesmen, industry research leaders, and academics well-

\footnotetext{
${ }^{3}$ See the Flemish government's VIA website for countless references to these European initiatives.
} 
knowledgeable of Flemish and European innovation policy and TA. These interviewees were identified through their association with TA or selected based on an initial analysis of newspaper coverage, innovation reports, policy memos, and agency documents, as well as legislation and records of parliamentary hearings dating back to the eighties. ${ }^{4}$ The historical overview presented in part 2 is followed by a section on the so-called Three Generations model of innovation from the innovation systems literature (part 3). Contemporary policy discourse (both Flemish and European) and TA language invoke this evolutionary model of technical change in pursuit of a more interactive and collaborative innovation process that involves actors from "all policy domains," including governments, industries, universities and schools, as well as "societal stakeholders" and wider publics (Larosse, 2004, p.6; Kuhlmann, 2001a). Thus, through the Generations model, TA and mainstream innovation discourse are potentially aligned. This alignment opens onto new, potentially powerful, STI articulations that may or may not evoke shared sense making among implicated actors. It therefore begs the question as to which role TA can, and should, play in present-day processes of "innovation governance" (Felt et al., 2007) (part 4).

We stress upfront that this study does not fully map the policy debate on innovation in Flanders or Europe. Rather, the emphasis is on TA actors and processes, and particularly on the broadening of innovation terms and actions through Flemish TA. The relatively small interview sample reflects this focus, as only a handful of people has profound expertise of Flemish TA. We hence caution against overstating the role TA in Flanders has played in broadening traditional, usually linear, views of innovation, even if our findings suggest that it has in important instances facilitated Flanders' transition to a KBE that seeks to be sustainable, inclusive, and democratic. The gradual institutional and public uptake of TA in Flanders bears witness to this interpretation, even if various context factors are always at play. We thus concur with Joss and Belucci $(2002$, p.9) that the actual performance of TA should always be understood as the interplay between the wider institutional and social settings in which TA is embedded and which no single actor can control. In other words, these settings co-evolve, as a change in the innovation system can influence the (expected) output of a TA activity, for instance.

By emphasizing the specific manners in which Flemish political culture, innovation system thinking, and TA dynamically co-evolve, this article seeks to accomplish two key aims: 1 . To provide a deeper historical and contextual understanding as to how TA emerged and developed with Flemish innovation policy and R\&D practice; 2 . To open new inroads towards analyzing and debating the socio-political dynamics in the evolution of TA in knowledge-driven economies.

\footnotetext{
${ }^{4}$ All interviews were held in Dutch and transcribed in that language based on repeated listening to the audiorecordings and interview notes we had taken. The interview approach was semi-structured, as we started from a number of key themes, such as the history of Flemish innovation, which are found in the abovementioned documentary sources. From a concern with securing credible interpretations and deepening the scope of the data, various respondents were interviewed up to four times. Of the ten interviewees who responded to an initial draft of this paper (which the first author circulated in April 2012), all affirmed the accuracy of our interpretations, although four added valuable comments, which led us to further nuance or accentuate particular points. A list of interviewees is provided in Appendix A. One respondent's name is not disclosed as she insisted on remaining anonymous.
} 
Upon attending to these objectives, the article reconsiders the relationship between TA, science and technology policymaking, and innovation governance. Although TA is often presented as a management or governance tool in the TA literature (Van Oudheusden, 2014a), TA processes enact, as well as counteract, dominant STI policies, and typically do so at the intersection of sociotechnical spheres, policies, and temporalities. How TA positions itself or is positioned in relation to these dominant policy paradigms is particularly relevant to consider in view of the Flemish government's 2012 decision to close its parliamentary TA agency, the Institute for Science and Technology. Whereas this decision appears largely out of sync with the institutional expansion of TA in other parts of Europe (e.g. in Wallonia and through the EU-wide PACITA project, on which more below), it coincides with the reorganization of the iconic Danish Board of Technology. Rendering explicit the interplay between TA and STI policies and institutions is hence important to understand longer-term STI dynamics, possibilities, and constraints both in and beyond Belgium, even when these possibilities are not immediately picked up or await enactment. It can also render explicit how the integration of social rationales into innovation elicits tensions and struggles among actors and programs, as prevalent policy concepts like open innovation or the presently fashionable notion of "responsible innovation" do not readily translate into innovation practice (Von Schomberg, 2012). The article thus paves the way for reflection on the evolving viability and utility of TA within contemporary KBEs, as TA and STI engage in an "innovation policy dance" (Kuhlmann et al., 2010, pp.7-8); that is, the two spheres interchange prevailing perspectives and approaches by "dancing" together. ${ }^{5}$ The Flemish TA experiences the article describes can thus serve STI policymakers, TA communities, and innovation scholars as resources to ponder the role, place, and orientation of regional, national, and transnational TA in the years ahead, as talk of broadening, deepening, and governing innovation gains policy traction.

\section{2. "Innovative Flanders": From Third Industrial Revolution to Third Generation Innovation Policy}

Since the 1970s, constitutional reforms have gradually transformed Belgium from a unified state into a federal one with communities, regions, and language areas. The reforms were enacted as a way of finding constitutional solutions for the problems between the country's Dutch and French speaking communities. As a consequence of these reforms, the Belgian innovation system came to be decentralized, based on a horizontal division of policy domains between the regions of Flanders (in the north), Wallonia (in the south), and the Brussels Capital region (in the center). Each entity now pursues, develops, and implements its own innovation policy, more or less independent from the federal state and from one another.

Although Flanders is presently the economically richer region, it lagged behind Wallonia until the middle of the twentieth century. It became more prosperous than Wallonia after the

\footnotetext{
${ }^{5}$ Alternatively, one could use the metaphor of "dancing partners," as does Rip (2002) to imply that innovation theory, policy, and practice dynamically interact.
} 
Second World War, following the decline of Wallonia's coal and iron industries. When the first ever Flemish Executive (the initial name for the Flemish government) came to power in the early 1980s, it made attempts to boost Flemish economic self-awareness and position Flanders as an industrial, entrepreneurial, high-tech region (Oosterlynck, 2006, p.98). Since then, largescale investments in biotechnology, new materials, broadband technology, microelectronics and nanotechnology have been made with measurable economic gains, and government agencies and institutes erected to support "innovative technological R\&D" (CCIP, 2008, p.27).

A determining figure in transforming Flanders into a new, invigorated economy after the economic crisis of the seventies was the then chair of the Flemish government, Gaston Geens. Geens launched "DIRV," which stands for Derde Industriële Revolutie Vlaanderen, literally Third Industrial Revolution Flanders. ${ }^{6}$ This action program was officially launched in 1982 . Geens repeatedly spoke of DIRV as an offensive policy to create new products, production methods, and markets for industries of the future (Vlaamse Raad, 1983). He also stressed that it was the government's task to stimulate innovation in new technologies, while entrepreneurs and industries designed concrete projects in tandem with research institutes, universities, and private companies. Oosterlynck (2006, p.98), in his political-economic study of regionalism in Flanders, sums up these key threads of DIRV as follows:

... the DIRV-action stressed the central role of the entrepreneur as the carrier of innovative potential. There was a strong focus on high technology industries and the role of the state was redefined as supplying the conditions for innovation to take place.

The effects of DIRV on innovation policy and practice are tangible, as the program lent support to various basic and applied technologies, including the highly promising and already emanating fields of biotechnology, new materials, and microelectronics. Less perceptibly, but equally important, DIRV delivered a decisive break with Flemish economic pessimism. As again Oosterlynck (2006, p.101) writes, although DIRV was an institutional policy effort, it was "primarily a campaign to raise awareness and promote new technologies and innovation." In that respect it was highly successful as well. ${ }^{7}$ Furthermore, DIRV was a conspicuous campaign, which served the Flemish government to present "a clear image of itself to the general public, with an offensive policy of its own, distinct from both Walloon policy and national policy" (Goorden, 2004, p.8).

\footnotetext{
${ }^{6}$ Following Larosse (2001), the First Industrial Revolution refers to the changes that took place in agriculture, mining, manufacturing, etc. in the $18^{\text {th }}$ century, and in which the region of Wallonia played a lead role on the European continent. The Second Industrial Revolution began around 1957, when the European Community was established. Thanks to its central geographical location, its highly educated, multilingual, and relatively cheap workforce, Flanders drew in multinational investments intended to supply the entire Community. However, the subsequent economic crisis threatened Flemish welfare, inciting a Third Industrial Revolution.

${ }^{7}$ To lend support to this assertion, Oosterlynck cites Paul Zeeuwts, a past chair of the government-funding agency IWT. Zeeuwts argues that "[n]obody, not even the staunchest critics of the DIRV action, dispute that it succeeded in breaking the economic pessimism of the Flemish population and business world and that it led to a renewed dynamism and courage (our translation)." René De Feyter, then head of the Flemish employers' organization and an important ally of Geens, argues that DIRV succeeded in inciting pride among Flemings, demonstrating that they could make things happen (Durnez \& Vandeborne, 2008).
} 
Various authors and interviewees hence identify DIRV as a "keystone" not just in instigating contemporary innovation policy in Flanders, but also acknowledge its role in the construction of Flanders as an innovation region, even if their appreciations of the program vary. For the purpose of this article it is important to note that actions like DIRV induced a range of politicaleconomic reforms that emphasized entrepreneurship and restricted Keynes-like state intervention in the economy. While these restructurings emerged in response to various international and domestic trends and challenges (e.g. the linguistic conflict in Belgium), they were also the result of ideological crafting and the search for new policy paradigms (Witte et al., 1997, p.321). It is partly against this background that ensuing programs, actions, and contestations in the Flemish innovation context should be understood, including the emergence of technology assessment and the broadening of the notion of innovation that TA engenders.

\section{Resistance to DIRV and scope for change}

As a program of large-scale reform, DIRV did not go uncontested. Strong opposition to DIRV came primarily from the political left, including the socialist trade union ABVV (representing traditional industries, among others), as well as one of its most vocal critics in the Flemish parliament, the socialist Norbert De Batselier, who after Geens went on to become the Minister of Economy. These actors criticized DIRV not just for its "liberal" emphasis on entrepreneurship and small government, but also for its neglect of "social dimensions" [Goorden, 2012]. ${ }^{8}$ From the trade union's point of view, the DIRV action was too much about rationalizing work and cutting jobs; a point they argued with the active support of labor sociologists from various universities, who were critical of the government's labor policies. The unions contended that DIRV lacked a broad debate about how to organize industry, the role of the state, and participation of the labor movement [Berckmans, 2012]. ${ }^{9}$ Similarly, the ABVV saw DIRV as too opportunistic, as the program emerged from the minds of an elite cadre of politicians, technocrats, and capitalists rather than through the more customary process of collective bargaining, which brings together trade unions, employers' organizations, and the government.

Given these expressed concerns and needs, various interviewees suggest a causal link between the above criticisms and Geens's establishment in 1984 of Stichting Technologie Vlaanderen (STV), which officially translates into Flemish Foundation for Technology Assessment [Berloznik, 2011; Goorden, 2012; Berckmans, 2012]. Similarly, in his biography of De Batselier, Hellinck (2010, p.128) states that STV was erected because the DIRV action failed to take into account "the impacts of new technology on society."

As a government-financed agency led by the social partners and embedded in the Social Economic Council of Flanders (SERV), STV's aim was to analyze the social dimensions of new technologies and advise the government on science and technology issues (SERV-STV, 1994;

\footnotetext{
${ }^{8}$ In this article, square brackets indicate that the quotes are taken from interviews.

${ }^{9}$ A point of view the ABVV shared with its sister organization, the Christian-Democrat trade union ACV.
} 
SERV, 1998; Goorden, 1990). One interviewee describes STV as a compromise between more "liberal" and "socialist" views of innovation policy, adding that although STV's mission was ambiguous from the start, the organization managed to "socially assist," and thus "soften," the transition of the Flemish economy to post-Fordism by questioning the assumption that technological growth automatically implies economic growth [Oosterlynck, 2010]. Other respondents argue that STV contributed to providing a more complex understanding of the relationship between innovation and labor in which the role of the government is redefined [Berloznik, 2011; Holemans, 2012; Larosse, 2011].

While it is hard to assess the precise contribution of STV to innovation policy, its erection in 1984 appears to have had some influence on the discourses of innovation at the time. This is not just because it was a consensually-managed advisory organization that had to take into account different political visions, but as one respondent who worked at STV points out, a leading politician like De Batselier literally integrated chunks of text from STV outlets in his parliamentary speeches [Goorden, 2012]. Consequently, the agency succeeded in introducing the notion of TA in the policy arena (Berckmans, 2007, p.84).

Other respondents acknowledge the influence of STV in shaping policy: "The introduction of technology assessments in organizational processes was in large part thanks to STV, and was rooted in the criticism that DIRV lacked consideration of social dimensions in innovation" [Berloznik, 2011; Maes, 2012]. Thus, through STV "innovation" was broadened to encompass other concerns than purely economic ones, such as the unions' concerns for wellbeing in the workplace, quality of work, and labor organization, and in a later stage also ethical and ecological aspects of technological innovation. ${ }^{10}$

\section{Further expanding the scope: Towards a Third Generation Innovation Policy}

After the regional elections of 1988, Flemish innovation policy officially fell in hands of the Socialist Party, much to the dismay of Geens (Hellinck, 2010, p.170). ${ }^{11}$ Since then, innovation thinking has shifted to a Third Generation Policy, on which more shortly. Although certain respondents relate these policy changes to shifts in the political landscape (i.e. the political actions that were taken to counter, or at least balance, DIRV reforms), structural factors are to be considered as well. According to Larosse (2001), the DIRV action, in promoting innovation as a distinct policy objective, instilled into the minds of Flemish policymakers an awareness of the $\mathrm{KBE}$, as knowledge generation and the economy were now seen as inextricably intertwined. Thus, the challenge for all policymakers both on the left and the right became one of reorganizing Flemish society in order to make better use of knowledge across borders and disciplines, which in turn stimulated entrepreneurs, researchers, and industries to pool resources. Importantly, this change also induced certain expansions in the sense that new

\footnotetext{
${ }^{10}$ Although STV initially developed a TA program, the agency later dropped TA from its "already considerably wideranging" agenda, choosing instead to focus on socio-economic matters (Berckmans, 2009). In June 2000, a parliamentary TA institution called viWTA was erected, on which more later.

${ }^{11}$ Although there was no Minister of Innovation or portfolio at the time, De Batselier took the lead in this policy area.
} 
actors, actions, and issues were brought to the policy table to make innovation policy more "coherent" (Van Humbeeck et al., 2004).

Without going into full detail, we attempt to capture the main tenets of the so-called Third Generation Innovation Policy (TGIP), as TGIP is an important "theoretical building block" from the innovation systems literature, which innovation actors in Flanders and the EU draw on to direct innovation [Larosse, 2011; Berloznik, 2013; Evers, 2013; Goorden, 2012] (Zeeuwts, 2004). TGIP also aligns with the theory of regional innovation systems that accompanied the emergence of regionally identifiable clusters of industrial activity, and which casts the region as the most appropriate scale at which to sustain innovation-based learning economies (Asheim \& Isaksen, 1997). This explains TGIP's popularity in Flanders, where policymakers and innovation actors look to establish Flanders as a leading innovation-led economy in the world and develop its cultural identity (Delvenne, 2011, p.224). As both TGIP and regional innovation systems theory are indebted to the evolutionary theory of technical change, they sustain the now prevalent reading of innovation as a creative process that benefits from collaborative interaction between innovation agents (Cooke et al., 2000).

Following Lengrand et al. (2002), this emphasis on interactive learning and joint knowledge building emerges in response to First and Second GIP. In Flanders, FGIP, is usually associated with the DIRV action and reflects the "linear model of innovation"; i.e. the idea that new processes and products are developed through scientific discovery in a laboratory and subsequently break through and are diffused on market. With FGIP, often characterized as a science-driven and "technology-push" approach (Berckmans, 2009), Flemish innovation policy selectively rewarded those research groups who placed their research activities explicitly in the domains government pushed for. With the aim of "picking winners," Flemish government encouraged world-class research in generic technology fields such as microelectronics. As a result, universities and public research institutions with an interuniversity structure became influential players in innovation. The institutional context in which they operated emphasized the central role of research actors in the innovation system with the focus on a science-driven philosophy.

SGIP, which came to the fore in the mid-nineties, offers a more integrated take on innovation, as it acknowledges the complex interplay between science, technology, and nontechnical groups of actors, such as social and economic sectors. In Flanders, this approach was reflected in government support of a bottom-up growth of innovation clusters as horizontal collaborations between all innovation actors (companies, universities, technological institutions, public administrations), with attention for spontaneous feedback loops between innovation phases. Following this thread of thought, the Flemish government sought to stimulate endogenous growth in Flanders by anchoring technological innovation in geographic regions and existing activities (Goorden et al., 2008, p.170). 
More recently, Flemish policymakers generally appeal to TGIP; officially at least, as certain aspects of FGIP and SGIP are still found in Flemish policy documents and practices. ${ }^{12}$ TGIP'S $^{\prime}$ importance is that it places innovation on the agenda of every policy domain, for instance in the areas of education, healthcare, and sustainable development. Consequently, innovation is to be developed interactively, as a systemic activity in which policy instruments are not only directed towards individual organizations (e.g. through R\&D subsidies) or bilateral relations (e.g. knowledge transfer), but also to the innovation system as a whole (e.g. managing interfaces and organizing learning platforms). From this perspective, it is necessary to identify the relevant stakeholders and involve them in the innovation process early on. Last, in a TGIP framework, it is important to provide good public information on important waves of innovation and ensure greater public involvement in decision making.

Table 1 summarizes the main tenets of each generation of innovation policy.

\section{INSERT [Table 1. Overview of the First, Second, and Third Generation of Innovation Policy]}

To offer an indication of how TGIP concepts infuse contemporary policy discourse, let us briefly consider the Pact 2020 (mentioned earlier), which is a much referred to "future plan" for Flanders, and which fits in the overarching framework of Flanders in Action (VIA). To begin with, the Pact aspires to providing a "social platform"; hence its signatories include not only the Flemish government, but also the social partners and civil society organizations, including environmental organizations. Secondly, the Pact projects a "long-term growth path" for Flanders by 2020 , with the aims of achieving greater prosperity and welfare and a competitive and sustainable economy. These aims constitute one "coherent" policy. Thus, we read that by 2020 "a proportionate participation in employment will be assured," "the demands of Work and Family are better attuned to one another," and $\mathrm{CO}_{2}$ emissions lowered in line with EU targets. As these objectives indicate, the scope of innovation is expanded to include not just economic goals (growth in a narrow sense), but sustainable development as the integration of economic, social, and ecological goals. Moreover, the expansion of economic goals to other type of policy goals is taken not in terms of constraints on growth following a zero-sum logic, but as part of a coherent social mission with a long-term development perspective for Flanders (Van Humbeeck et al., 2004).

The Pact's significance is that it broadens the notion of innovation in ways that are conducive to TA principles and programs; notably through the shift from linear models of innovation to interactive ones, the broadening of actors and issues in innovation, and talk of collaborative learning and innovation governance. These principles are consistent with the EU's governance approach, as articulated in the European Commission's 2001 White Paper on European Governance, which, like Flemish innovation policy, draws inspiration from the innovation

\footnotetext{
${ }^{12}$ As Lengrand et al. (2002) note, "[t]here are dangers in announcing the imminence of a 'third generation' policy, when progress still needs to be made to make the second generation a reality!" Clearly, First and Second Generations ways of thinking about innovation co-exist with Third Generation language and concepts.
} 
systems literature (e.g. CEC, 2001). They also open to more inclusive and participatory ways of organizing innovation, in line with the EU's Science in Society Action Plan (e.g. CEC, 2002, p.6). ${ }^{13}$

We turn to an example of public participation in STI below, where we situate a Flemish participatory TA on nanotechnologies. For now, let us return to the DIRV campaign to situate the emergence of successive Flemish TA waves in relation to EU-wide STI policy.

\section{Three TA waves}

Not long after the end of the DIRV action and the erection of STV, the first TA initiatives were launched as academic research programs. As these programs were charged with examining the social impacts of new technologies such as biotechnology and microelectronics, the need for TA research was framed within the dominant science-driven and technology-push approach; i.e. in terms of predicting the social impacts of science and technology in order to adequately steer and orient governmental research and technology programs. One could say that TA was assigned the task of giving public governance a helping hand in "picking winners." As such, the initiatives represented an instrumental type of TA in which the social scientific and policy analytic approaches of experts dominate (Guston \& Sarewitz, 2002). Following Goorden (2004, p.11), we label this kind of TA early-warning TA because of its investment in technological prediction, control of (negative) impacts, and scientific expertise. ${ }^{14}$

As indicated earlier, from the nineties onwards there was a growing responsiveness to the idea that Flemish innovation policy needed a shift in focus, departing from a technology-push approach to striving for a policy that stresses the importance of technology diffusion. Policymakers therefore called for a kind of bottom-up TA, which they described as an approach "that may not slow down or have a negative influence on creativity and the innovation process." ${ }^{15}$ To this end TA activities had to be organized in close interaction with R\&D practices in governmental technological programs on biotechnology, new materials and energy, and environmental technology. The expectation was that if TA were practiced in direct consultation with science and technology producers, research would lead to socially useful applications. A parallel can be drawn here with constructive TA (CTA), which emerged a few years earlier in the Netherlands. Like CTA, bottom-up TA sought to broaden the design, development, and implementation of ongoing technology developments by initiating dialogue among innovation

\footnotetext{
${ }^{13}$ Hence, we find in the Flemish Minister of Innovation's 2010 Policy Memorandum on Innovation an explicit reference to the EU Science in Society Action Plan and an endorsement of public participation in science and technology: "In order to permanently turn Flanders into a successful knowledge society, it is essential that societal needs and concerns are integrated through ongoing democratic debate with a more involved and more informed public, and with better opportunities for making collective choices as regards science and technology issues (our translation)" (Vlaams Parlement, 2010, p.36).

${ }^{14}$ Other designations that underline the instrumental and control character of TA could also apply, such as expert TA or classical TA. For an instructive overview of these and other kinds of TA, see Decker and Ladikas (2004, p.14), Van Est and Brom (2012), and Ely et al. (2014).

${ }^{15}$ Technology Note of the Flemish government (1994).
} 
actors about (R\&D) design practices (Schot \& Rip, 1997). However, as the quote above indicates, Flemish policymakers took explicit care to channel (if not contain) the potential impact of this type of TA on the innovation process.

The shift from early-warning TA to bottom-up TA can be illustrated by comparing two Flemish policy documents on biotechnology, which outline the role of TA in this technology domain. ${ }^{16}$ In the first document, entitled Action Program for Biotechnology, and written by the Prime Minister, Geens, we read that the successful implementation of new biotechnology R\&D depends on "social, economic, legal, and ecological boundary conditions," as these conditions set a context for biotechnology development (Geens, 1988; emphasis added). In the second, written two years later by an advisor to minister De Batselier, the author similarly urges TA researchers to consider the "social, economic, legal, and ecological aspects" of biotechnology. However, she adds that these aspects are "not boundary conditions, but essential elements for modulating and orienting" the biotechnology program as a whole (Vervliet, 1990, cited in Holemans, 1994; emphasis added). Thus, whereas in the action program TA is cast as a corrective mechanism in order to develop a "favourable social climate" for technology development (Geens, 1987, p.177), the second document proposes a more integrated method, which directs attention to the aforementioned social and other aspects in technology development through dialogue between multiple disciplines.

A similar emphasis on creating a more integrated technology approach is found in other Flemish technology programs at the time (e.g. energy technology, environmental technology, and new materials). ${ }^{17}$ To sustain such an approach, TA research units in each program were set up. Each of these units was charged with studying the social effects of the technologies at hand. The units would stimulate dialogue among technology developers, social partners, and the government, and also seek to broaden the scope of debate by opening the possible negative effects of technology innovation to debate, for instance in the areas of environment, health, safety, and law.

Today, both the early-warning and bottom-up approaches are considered outdated. Goorden and Deblonde (2011) contend that top-down academic experiences involving early warning mechanisms for negative impacts of new technologies have not led to a reorientation of research programs or technology trajectories. In order to create a more interactive type of TA in which civil society and citizens participate, TA was lodged in an institution advising the Flemish parliament in the year 2000, the Flemish Institute for Science and Technology Assessment, viWTA (later renamed IST). The institute sought to stimulate social debate on sociotechnical developments and inform MPs of the social and ethical implications of science and technology. Importantly, with the erection of viWTA, TA was removed from the R\&D enterprise. Thus, contrary to several STV programs and initiatives like the action program on

\footnotetext{
${ }^{16}$ We are grateful to Dirk Holemans for directing us to these documents and pointing out the distinctions between them.

${ }^{17}$ As mentioned earlier, the idea of integrating TA into technology policy was a central concern of the then Flemish Minister of Economy. This is indicated by his resolve to "(...) weave technology assessment into all the facets of technology policy (our translation)." (Vlaamse Raad, 1991, p.4).
} 
biotechnologies mentioned above, TA was not fully ingrained in the innovation process but took place in a different location and time.

In this respect, developing timely participatory TA frameworks and procedures to effectively deal with the emergence of new and emerging technologies remained a big challenge for Flemish innovation policy. In a survey published by viwTA, a group of R\&D directors from companies, universities, and public administrations voiced some expectations and concerns. They stated that public governance should play the role of mentor by creating and governing new ways of collaboration among all relevant social actors. Second, they underlined the need for a collective vision and the formulation of social demands in relation to the policy goal of spending 3\% of Flanders' Gross Regional Product on R\&D by 2010. Third, given the lack of broad public support for technological innovation in Flanders, science and technology should have a more prominent place on the public agenda.

In response to these policy calls for a more integrated and inclusive innovation policy, the Flemish government endorsed a large participatory TA project on nanotechnologies in 2006, entitled Nanotechnologies for Tomorrow's Society (NanoSoc). NanoSoc sought to develop new forms of collaboration in which all social actors stimulate technology innovation and R\&D receives broad public support (Goorden et al., 2008, pp.171-172). The project approach was novel to Flanders, as social scientists working in TA took the lead throughout the project's duration rather than engineers or technologists. Second, the project sought to provide nanotechnologists in Flanders with incentives to reflect on social and ethical issues in relation to nanotechnology development so such considerations are brought to bear on their work. To this end, successive participation rounds were initiated involving nanotechnologists, stakeholders, and citizens. These rounds were initiated before and during actual nanotechnology R\&D stages in research centers in order to allow timely adjustment of strategic research agendas. NanoSoc thus pulled out researchers from their labs in an effort to initiate broad-range, interactive TA. The project drew inspiration from contemporary TA forms designed to "open up" and "broaden out" the social appraisal of technology (Stirling, 2008; Ely et al., 2014). These forms included real-time TA (Guston \& Sarewitz, 2002), constructive TA (Schot \& Rip, 1997), interactive TA (Grin et al., 1997), and the TA-related approach of upstream public engagement (Macnaghten et al., 2005). In line with these frameworks, NanoSoc sought to instigate an ongoing, deliberative role-principles dialogue on technoscientific responsibility that implicates wider society and scientists on the work floor, ultimately with the aim of developing an interactive methodology for socially responsible technology development (Goorden \& Deblonde, 2011). Hence, it took the role of TA in Flemish innovation a step further than we have seen thus far. ${ }^{18}$

Having outlined the range of Flemish TA approaches, let us consider how the three TA waves described above (early-warning, bottom-up, and interactive) link to the three generations of

\footnotetext{
${ }^{18}$ For more on NanoSoc and the TA approaches that informed it, see Goorden et al. (2008) and Van Oudheusden (2014b).
} 
innovation policy presented earlier. Figure 1 positions each wave in relation to one or more generations.

\section{INSERT [Figure 1. TA waves in relation to Generations of Innovation Policy]}

In the figure above, TA is presented as the interplay between innovation programs (FGIP, SGIP, TGIP) and technologies. The term technology here comprises "a range of devices, instruments, calculations and inscriptions," which articulate and make operable (Miller \& O'Leary, 2007). Seen through this sociopolitical lens of enactment and fabrication, early-warning TA mediates the transition from FGIP to SGIP, whereas bottom-up TA and interactive TA mediate the transition from FGIP and SGIP to TGIP, albeit by emphasizing different aspects. It is important to note that this classification stresses the mediating potential of TA. In reality, intervention does not amount to simply implementing schemes or theories. Nor are the generations and TA waves distinct historical stages that follow one another in an inevitable sequence; rather, various elements combine, depending on local context. For instance, early-warning TA served both a technology-push strategy and enabled social partners to articulate previously unconsidered social needs. Or, to give another example, whereas with bottom-up TA the aim was to integrate TA into technology programs, today TA is no longer an integral component of Flemish technology policy.

We conclude this section by reiterating the different roles TA practices have played in Flanders to this day. While in general terms, TA mediated between economic and technological rationales on the one hand, and social and environmental concerns, on the other, TA was implanted in several Flemish technology action programs in the 1980s-90s. In subsequent years, TA took on the form of a policy tool liked to parliament, as well as a more experimental, interactive form tied to the abovementioned contemporary international TA frameworks.

\section{Discussion: Quo Vadis TA?}

What do we learn from the Flemish TA experiences and how do these relate to STI developments more broadly? In this section, we provide three answers to these questions by outlining defining features of Flemish TA and STI, which we infer from our historical and sociological overview. Our responses emerge in the context of recent, cross-regional and crossnational STI and TA developments, notably the EU policy shift towards responsible innovation governance and the potential expansion of TA activities in Wallonia and elsewhere in Europe.

A first important observation is that Flemish TA emerged and matured in a strategic, knowledge-centered STI environment; i.e. an environment that forges new alliances between the scientific establishment, policymakers, and societal actors for the sake of science-driven economic development. As Delvenne (2011, p.335; Delvenne et al., 2011) notes in his study of European parliamentary TA institutes, the institutionalization of TA may well depend upon the 
emergence of strategic science as a new mode of knowledge production. Following Rip (2002), strategic science heralds a shift in scientific knowledge production from relatively isolated, "basic," academic research, to research that is economically and socially relevant and that can only be understood within a context of application. As we have seen, TA potentially transforms this context by bringing more diverse epistemic cultures and "knowledges" into STI processes. Knowledge here no longer only refers to intellectual property, technological applications, and scientific beliefs, but also, and increasingly so, to new kinds of expertise (e.g. sociological, lay, indigenous), to new forms and manifestations of relevance (e.g. social and ecological concerns, mutual learning, and the acquisition of skills), and the democratization of sociotechnical culture at large (Knorr-Cetina, 1999: 8; Bijker, 1995). TA can thus contribute to broadening, deepening, and governing knowledge in contemporary KBEs, which is precisely what STI policymakers and various innovation enactors claim innovation is, or should be, about (Stilgoe et al., 2013; Ely et al., 2014). ${ }^{19}$

The development of TA in other KBE contexts (e.g. the Netherlands, Denmark, Germany) lends weight to the above hypothesis, as does the emergence of significant EU-wide Science in Society projects like Parliaments and Civil Society in Technology Assessment (PACITA; 2011-20145) and previous initiatives like EUROPTA. ${ }^{20}$ While it is too early to establish PACITA's policy impacts, it is important to note that PACITA is designed to facilitate "coordination and networking activities, dissemination and use of knowledge" in support of research activities and policies across Europe. In fact, PACITA is construed as a "Mobilisation and Mutual Learning Action Plan [that] will distribute capacity and enhance the institutional foundation for knowledge-based policy-making on issues involving science, technology and innovation (...)."21

The potential influence of PACITA is felt in Wallonia, which contrary to Flanders has not institutionalized TA, but which now explicitly gears its STI policy towards the KBE and strategic science (e.g. Plan Marshall, 2022). At present, TA advocates and policymakers debate the opportunity of establishing a Walloon TA institute linked to the Walloon parliament. They do so with the explicit aim of rendering TA serviceable to Walloon STI policymaking, in line with PACITA's aims of activating multiple kinds of knowledge and engaging multiple societal actors in STI decision making (Van Oudheusden, 2013).

\footnotetext{
${ }^{19}$ Consider in this light the various citations of Flemish STI policy documents provided in this article's introduction. Consider also the many EU policy discourses on integrating science in society for the sake of good innovation governance. For instance, in a 2013 Expert Group Report to the EU's Directorate General for Research and Innovation, we read that "The [Responsible Research and Innovation] approach has to be a key part of the research and innovation process and should be established as a collective, inclusive and system-wide approach" (downloaded on 14 October 2013 from http://ec.europa.eu/research/sciencesociety/document_library/pdf_06/options-forstrengthening_en.pdf).

${ }^{20}$ This EUROPTA research project was initiated by the Danish Board of Technology within the European Participatory TA network EPTA; see www.eptanetwork.org. Other, related, initiatives include those implemented by the European Parliament's Science and Technology Options Assessment unit, STOA; see www.europarl.europa.eu/stoa.

${ }^{21}$ Downloaded on 8 August 2014 from http://cordis.europa.eu/project/rcn/98487_en.html.
} 
Based on these examples, it would appear that TA not only relies on, but thrives in, the context of knowledge-driven innovation. However, if TA is to exert a lasting influence in the KBE, TA actors must render clear to policymakers and innovation actors TA's credentials as a decisive knowledge player. Recent developments, such as the closing of the Flemish parliamentary TA institute, IST, and the restructuring of the DBT by the Flemish and Danish government, suggest that these credentials cannot be taken for granted. We return to this point shortly.

Second, and in relation to our first observation, Flemish TA taps into a political culture that emphasizes the importance of social concertation. In countries like Belgium (but also Switzerland, the Netherlands, and some would argue the EU at large), collective bargaining between trade unions, employers' organizations, and governments is an important political and social tradition that allows TA practices to gain a firm foothold in multi-layered, consociational democracies (Lijphart, 1977). The erection of the Flemish TA institute STV in response to the DIRV campaign illustrates this point, as trade unions demanded their say in STI policymaking. Seen in this way, TA can arbitrate between scientific, political, and social worlds. When TA is integrated into R\&D settings (e.g. Flemish technology action programs) and/or embedded in formal policymaking bodies, it can open onto new negotiation practices and establish a more integrative decision-making culture. TA can hence contribute to "strengthening more responsive relations in the governance of innovation" (Ely et al., 2014); by promoting various kinds of communication among concerned actors (government, social partners, academia, citizens), by developing democratically legitimate meeting spaces for these actors and their concerns, or simply by reopening debate on sociotechnical issues (Bütschi \& Nentwich, 2002, p.240).

However, the institutionalization of TA entails risks, as well as opportunities. As noted earlier, when the IST (formerly viwTA) was installed in the Flemish parliament in 2000, TA was physically removed from the R\&D process. Thus, while TA gained a foothold within formal Flemish policy circles, it became less ingrained in scientific and technological research activities across the region. Second, as Horst (2012) argues in relation to the restructuring of the DBT by the Danish government in 2011, when TA is embedded within formal policymaking bodies and processes, it risks being domesticated or "tamed." This is because ideas, roles, and values that were once considered new subsequently become the norm. When these new norms are socially established, innovation typically takes on other challenges, forms, and orientations. Established organizations may then find it hard to change, adapt, and reposition themselves to meet new needs in complex and changing environments, and may even become obsolete (Gubrium \& Holstein, 2001). As Horst notes, in Denmark democratic debate about science and technology lost momentum after the DBT's institutionalization in 1986. In the years that followed, Danes came to take debate of this kind for granted. In fact, many Danes appeared ignorant of the DBT's existence.

Whether or not similar assertions can be made about the closing of the Flemish IST is an open question. As with any institutional reform, the reasons for the IST's closure are manifold and complex; they pertain to the institute's ambiguous public identity and its relation to parliament and governmental agencies, the multiple missions inscribed in its statutes, and to how the IST 
was managed on a day-to-day basis, among others. ${ }^{22}$ Rather than develop these reasons in detail, we draw attention to a third important feature of Flemish TA as a whole, which complements the interpretation that established institutes like IST fail to reposition themselves in light of new challenges. Various Flemish politicians, industry actors, and scientists argue that Flemish TA is not a neutral governance tool, but politically partisan, as TA emanated on the left side of the political spectrum; specifically among the green and socialist parties. The establishment of STV in response to the DIRV campaign renders explicit how Flemish TA has politics, to paraphrase Langdon Winner (1980). Politics here is defined as achieving and exercising positions of influence within, and through, organized party politics. Given Flanders' multiparty political system, these politics provide an often overlooked explanation as to why the IST was dismantled, as since 2009 Flemings have increasingly voted for right-wing, conservative parties that are at best indifferent to TA and at worst vehemently opposed to it. As noted elsewhere (Van Oudheusden, 2014a), TA's political affiliations are often denied or downplayed across TA communities. TA is typically framed as an analytic activity aimed at providing decision makers with an objective analysis of a technology (Van Eijndhoven, 1997) and/or as an interactive and communicative tool that aims to enrich the basis for STI decision making (Decker \& Ladikas, 2004). While some policymakers may find these broad designations (i.e. geared towards all political factions and to the benefit of all innovation actors) of TA compelling, they risk trivializing and undermining the very policy changes TA advocates seek to instigate when TA is associated with specific political parties or politicians. ${ }^{23}$

These considerations call into question the widely shared assumption among TA proponents and some policymakers that TA and responsible innovation go hand in hand (Von Schomberg, 2012). Whereas TA is correctly ascribed great potential as a tool for strategic intelligence (Kuhlmann, 2001b) and democratic innovation governance (Bijker, 2013), the developments in Flanders (and Denmark) point to potentially significant pitfalls inherent in institutionalizing TA and in aligning technological, economic, and social rationales in the first place. Connecting and coordinating TA experiments through cross-national, networked programs like PACITA is a possible means of attending to such pitfalls (Ely et al., 2014). Yet, to further maximize collective learning among these networks, and to more fully grasp the mechanisms of innovation governance at large, the uncertainties and paradoxes in TA practices should be debated headon and addressed by TA communities, policymakers, and innovation scholars.

\section{Conclusion}

This article describes how Flemish technology assessment (TA) initiatives have unfolded with Flemish science, technology, and innovation (STI) policies from the 1980s to the present day. Building on a historical review of Flemish STI and TA processes, it links various TA strands (early-

\footnotetext{
${ }^{22}$ These assertions are based on interviews the first author had with former IST staff, politicians, and implicated others; as is the understanding that "TA has politics" below.

${ }^{23} \mathrm{Here}$, an instructive comparison could be drawn with the American Office of Technology Assessment (OTA), which US Congress abolished in 1995. A former OTA staff member, Todd LaPorte (2013), argues that OTA was not always perceived of as neutral and independent; rather, it was associated with (certain) Democrats.
} 
warning, bottom-up, and interactive TA) to different generations of innovation thinking in Europe. The article suggests that Flemish TA contested and complemented Flemish innovation policies; typically by bringing new actors (e.g. trade unions) and issues (e.g. ecological concerns) to the policy innovation table and by stimulating more interactive kinds of STI decision making.

In the process, tensions and struggles emerged between TA aspirations and STI policies. Arguably, these tensions were most potent in the early eighties, when TA emerged as a counterforce to the dominant technology- and economy-driven DIRV campaign of the Flemish government. Yet, even after the institutionalization of TA in the Flemish parliament in 2000 and the now general acknowledgment of the importance of cooperation and social responsibility in STI, TA remains a fragile knowledge-based economy (KBE)-instrument, highly dependent on economic and social forces and dynamics. These forces also include politics, as Flemish TA is historically affiliated with the green and socialist parties.

These observations raise a number of intriguing questions about the role and potential of TA in contemporary KBEs. To the extent that TA is read as a distinct alternative to the market that fundamentally challenges the way innovation is done, TA aspirations cannot simply be integrated into the dominant growth images. Conversely, the institutionalization of TA may imply a "taming" of TA's unruly and policy-critical potential, as TA actors, concepts, resources, etc., are "blended into the establishment" (Horst, 2012). By implication, TA loses some of its critical clout, as TA language, objects, and acts are, or can be, appropriated into business-asusual.

Given the institutional disintegration of TA in certain places and its potential expansion in others, it is important to understand how TA positions itself, or is positioned, in relation to policy at large and innovation policies specifically. While care should be taken not to exaggerate TA's role in bringing about STI policy change, its potential as a conduit for sociotechnical innovation should not be minimized either. This is because TA operates within, and through, the confines of particular ideological STI systems and unfolds with the advent of strategic science and the KBE. At the very least, it is indicative of actual and pending shifts in STI policies, such as the present-day evolutions towards more open innovation, responsible innovation, and innovation governance, which play out across Europe, the United States, and elsewhere.

For these reasons, the Flemish experiments with TA should incite critical reflection among TA communities and innovation scholars on TA's strategic usefulness for policymakers, innovation entrepreneurs, civil society organizations, scientists, technologists, and publics. Clearly, if TAs are to exert a lasting influence, TA actors must render clear to these actors TA's credentials as a decisive knowledge player in the KBE. Failure to do so risks undermining TA's relevance, to use a strategic science term. In turn, policymakers and innovation scholars can draw on the Flemish TA case to question and perhaps refine contemporary notions of innovation, as "innovation governance" gains ever more public acclaim and policy momentum.

\section{Acknowledgments}


This paper has greatly benefited from comments provided by two anonymous reviewers, and from suggestions made by Maja Horst, Erik Fisher, and members of his research project "SocioTechnical Integration Research." The material this article contains is partly based upon work supported by the Fonds de la Recherche Scientifique (FNRS) and the National Science Foundation (NSF) under Grant No. 0849101.

\section{References}

Asheim, B., Isaksen, A., 1997. Location, Agglomeration and Innovation: Towards Regional Innovation Systems in Norway? European Planning Studies 5(3), 299-330.

Berckmans, P., 2007. De verruiming van het innovatiedenken en -doen en de rol daarbij van de Vlaamse sociale partners. In: Devos, J. \& De Cock, O. (Eds.), Strategische intelligentie over innovatie in Vlaanderen. Agentschap voor Innovatie door Wetenschap en Technologie (IWT), Brussels, pp. 80-92.

Berckmans, P., 2009. Impressies over 25 jaar STV, Interne Nota Stichting Innovatie en Arbeid, Brussels.

Bijker, W., 1995. Of bicycles, bakelites and bulbs: Toward a Theory of Sociotechnical Change. MIT Press, Cambridge.

Bijker, W., 2013. Technology Assessment: The State of Play. Towards a Hybrid and Pluriform Process of Governance of Science and Technology. In: Michalek, T. et al. (Eds.), Technology Assessment and Policy Areas of Great Transitions. Proceedings from the PACITA 2013 Conference, Prague, pp. 23-36.

Bütschi, D., Nentwich, M., 2002. The Role of Participatory Technology Assessment in the Policy-Making Process. In: Joss, S. \& Belluci, S. (Eds.), Participatory Technology Assessment. European Perspectives. Science Museum with the Support of the European Commission Directorate General XII, London, pp. 235-256.

Commission of the European Commission (CEC), 2001. European Governance. A White Paper, Brussels, $\operatorname{COM}(2001) 428$.

--- 2002. Science and Society Action Plan, Brussels.

Committee on Comparative Innovation Policy (CCIP), 2008. Innovative Flanders: Innovation Policies for the $21^{\text {st }}$ Century: Report of a Symposium. In: Esner, C.W. (Ed.), National Academies Press, Washington, D.C., http://www.nap.edu/catalog/12092.html

Cooke, P., Boekholt, P., Tödtling, F., 2000. The governance of innovation in Europe: Regional perspectives on global competitiveness. Pinter, London.

Decker, M., Ladikas, M., 2004. Bridges between Science, Society and Policy. Springer Verlag, Berlin. 
Delvenne, P., 2011. Science, technologie et innovation sur le chemin de la réflexivité. Mise en perspective des offices parlementaires de Technology Assessment. Academia L'Harmattan, Louvain-laNeuve.

Delvenne, P., Fallon, C., Brunet, S., 2011. Parliamentary Technology Assessment as Indications of Reflexive Modernization. Technology in Society 33(1-2), 36-43.

Durnez, E. \& Vandeborne, P., 2008. Flanders Technology of de uitvinding van de Vlaamse trots. Vokatribune, May 6, 2008.

Ely, A., Van Zwanenberg, P., Stirling, A., 2014. Broadening and opening up technology assessment: Approaches to enhance international development, co-ordination and democratisation. Research Policy 43, 505-518.

Felin, T., Zenger, T.R., 2013. Closed or open innovation? Problem solving and the governance choice. Research Policy 43, 914-925.

Felt, U., Wynne, B., Callon, M., Goncalves, M., Jasanoff, S., Jepsen, M., Joly, P.-B.,Konopasek, Z., May, S., Neubauer, C., Rip, A., Siune, K., Stirling, A., Tallachini, M., 2007. Science and Governance: Taking European Knowledge Society Seriously, Report to of the Expert Group on Science and Governance to DG Research.

Ganzevles, J., Van Est, R. (Eds.), 2012. TA Practices in Europe. PACITA Project.

Ganzevles, J., Van Est, R., Nentwich, M., 2014. Embracing variety: introducing the inclusive modelling of (Parliamentary) technology assessment. Journal of Responsible Innovation 1(3), 292-313.

Geens, G., 1987. Op eigen kracht. Richting geven aan Vlaanderen. Lannoo, Tielt.

Geens, G., 1988. Voorstel van een Vlaams actieprogramma biotechnologie, Nota aan de Leden van de Vlaamse Executieve, Brussels.

Goorden, L., 1990. De Stichting Technologie Vlaanderen en Technology Assessment. Tijdschrift voor Arbeidsvraagstukken 6(2), 79-89.

Goorden, L. 2004. Innovation Policy and Technology Assessment in Flanders, Study commissioned by the Flemish Institute for Science and Technology Assessment (viwTA), University of Antwerp, Antwerp.

Goorden, L., Van Oudheusden, M., Evers, J., Deblonde, M., 2008. Nanotechnologies for Tomorrow's Society: A Case for Reflective Action Research in Flanders, Belgium. In: Fisher, E., Selin, C., Wetmore, J. (Eds.), Presenting Futures. Yearbook of Nanotechnology in Society, Vol. 1, Springer Science and Business Media, Dordrecht, pp. 163-182.

Goorden, L., Deblonde, M., 2011. Navigating in Nanospace: Presentation of an Integrated Roadmap, Final Report NanoSoc, http://www.nanosoc.be/Pub/Final\%20Report\%20NanoSoc\%20Navigating\%20in\%20Nanospace\%20Pres entation\%20of\%20an\%20integrated\%20roadmap_ENG.pdf 
Grin, J., van de Graaf, H., Hoppe, R., 1997. Technology Assessment through Interaction. A Guide. Rathenau Instituut, The Hague.

Guston, D., Sarewitz, D., 2002. Real-time technology assessment. Technology in Society 24(1), 93-109.

Hellinck, B., 2010. Norbert De Batselier. Een leven in de politiek. Manteau, Antwerp.

Hennen, L., 1999. Participatory technology assessment: A response to technical modernity? Science and Public Policy 26(5), 303-312.

Holemans, D., 1994. Naar een sociaal-ekologisch technologiebeleid, Discussietekst Anders GAan LEVen (AGALEV), Brussels.

Horst, M., 2014. On the weakness of strong ties. Public Understanding of Science 23, 43-47.

Joss, S., Belucci, S., 2002. Participatory Technology Assessment. European Perspectives. Science Museum with the Support of the European Commission Directorate General XII, London.

Knorr-Cetina, K., 1999. Epistemic Cultures. Harvard University Press, Harvard.

Kondartiev, N., 1978. The Long wave in economic Life (trans. W. Stolper). Lloyds Bank Review 129, 4160 .

Kuhlmann, S., 2001a. Future governance of innovation policy in Europe - three scenarios. Research Policy 30, 953-976.

Kuhlmann, S., 2001b. Evaluation as a source of strategic intelligence. In: Shapira, P., Kuhlmann, S. (Eds.), Proceedings from the 2000 US-European Workshop on Learning from Science and Technology Policy Evaluation, Bad Herrenalb, pp. 11.21-11.59.

Kuhlmann, S., Shapira, P., Smits, R., 2010. Introduction. A Systemic Perspective: The Innovation Policy Dance. In: Smits, R., Kuhlmann, S., Shapira, P. (Eds.), The theory and practice of innovation policy. Edward Elgar, Cheltenham, pp. 1-24.

LaPorte, T., 2013. Technology Assessment at the American Congress and the future of Technology Assessment, Presentation at a Symposium on Technology Assessment in the Walloon Parliament, Namur, March 8, 2013.

Larosse, J., 2001. De ontwikkeling van het innovatiebeleid en de opkomst van een 'Nieuwe Economie' in Vlaanderen, Rapport belge en matière de science, technologie et innovation, 55-75.

Larosse, J., 2004. Towards a 'Third Generation' Innovation Policy in Flanders: Policy Profile of the Flemish Innovation System. Contribution to the OECD-TIP Project MONIT 49, Agentschap voor Innovatie door Wetenschap en Technologie (IWT), Brussels.

Lengrand, L. et al., 2002. Innovation Tomorrow. Innovation policy and the regulatory framework: Making innovation an integral part of the broader structural agenda, European Commission, Brussels, 
http://cordis.europa.eu/innovation-policy/studies/gen_study7.htm\#download

Lijphart, A., 1977. Democracy in plural societies: A comparative exploration. Yale University Press, New Haven.

Lundvall, B-Å., 1992. National Systems of Innovation: Towards a Theory of Innovation and Interactive Learning. Pinter, London.

Macnaghten, P., Kearnes, M., Wynne, B., 2005. Nanotechnology, Governance, and Public Deliberation: What Role for the Social Sciences? Science Communication 27(2), 1-24.

Miller, P., O'Leary, T., 2007. Mediating Instruments and Making Markets: Capital Budgeting, Science and the Economy. Accounting, Organizations and Society 32, 701-734.

Oosterlynck, S., 2006. The political economy of regionalism in Belgium: imagining and institutionalising the Flemish regional economy, unpublished PhD dissertation, Lancaster.

Organization for Economic Cooperation and Development (OECD), 2010. Innovation Strategy: Getting a Head Start on Tomorrow, Directorate for Science, Technology and Industry, May 2010, 225p.

Rip, A., 1992. Science and technology as dancing partners. In: Kroes, P., Bakker M. (Eds.), Technological Development and Science in the Industrial Age. Kluwer Academic, Dordrecht, pp. 231-270.

Rip, A., 2000, Fashions, Lock-Ins, and the Heterogeneity of Knowledge Production. In: Jacob, M., Hellström, T.A. (Eds.), The Future of Knowledge Production in the Academy. Open University Press, Buckingham, pp. 28-39.

Rodmeyer, M., Sarewitz, D., Wilsdon, J., 2005. The Future of Technology Assessment.Woodrow Wilson International Center for Scholars, Washington DC.

Schot, J., Rip, A., 1997. The past and future of constructive technology assessment. Technology Forecasting and Social Change 54(2\&3), 251-68.

Schumpeter, J., 1939. Business Cycles. McGraw Hill, New York.

Sociaal-Economische Raad Vlaanderen \& Stichting Technologie Vlaanderen (SERV), 1994. De Vlaamse technologieprogramma's. Enkele ervaringen met Technology Assessment, Brussels.

--- 1998. Advies over het voorontwerp van decreet betreffende het voeren van een beleid ter aanmoediging van de technologische innovatie, Brussels.

Stilgoe, J., Owen, R., Macnaghten, P., 2013. Developing a Framework for Responsible Innovation. Research Policy 42(9), 1568-1580.

Stirling, A., 2008. 'Opening Up' and 'Closing Down'. Power, Participation, and Pluralism in the Social Appraisal of Technology. Science, Technology, \& Human Values, 33(2), 262-294. 
Van Eijndhoven, J., 1997. Technology Assessment: Product or Process? Technological Forecasting and Social Change 54(2), 269-286.

Van Est, R., Brom, F., 2012. Technology Assessment: Analytic and Democratic Practice. In: Chadwick, R. (Ed.), Encyclopedia of Applied Ethics: Second Edition Vol. 4, Academic Press, San Diego, pp. 306-320.

Van Humbeeck, P., Dries, I., Larosse, J., 2004. Linking Innovation Policy and Sustainable Development in Flanders, Contribution to the OECD-TIP Project MONIT, IWT Observatory, Brussels, 64p.

Van Oudheusden, M., 2013. Broadening the Knowledge Base in Policymaking: Notes on a Symposium on Technology Assessment in the Walloon Parliament. EASST Review, June 2013.

Van Oudheusden, M., 2014a. Where are the politics in responsible innovation? European governance, technology assessments, and beyond. Journal of Responsible Innovation 1(1), 67-86.

Van Oudheusden, M., 2014b. Learning in, through, and about participatory technology assessment: the case of Nanotechnologies for Tomorrow's Society. Technology Analysis \& Strategic Management 26(7), 825-836.

Vervliet, G., 2006. Science, Technology, and Innovation. Ministry of Flanders, Science and Innovation Administration, Brussels.

Vlaams Instituut voor Wetenschappelijk en Technologisch Aspectenonderzoek (viwTA), 2004. Memorandum over het innovatiebeleid in Vlaanderen, Brussels.

--- (2005), Welkomtoespraak Norbert De Batselier, EPTA Conferentie, Brussels.

Vlaams Parlement, 2010. Beleidsbrief Innovatie 2010-2011, 774(2010-2011) - Nr. 1, 28 October, 2011.

Vlaamse Raad, 1983. Ontwerp van decreet houdende de begroting van de Vlaamse Gemeenschap voor het begrotingsjaar 1983, Stuk 8 (1982-1983) - Nr. 3.

Vlaamse Raad, 1991. Beleidsbrief Technologiebeleid in Vlaanderen, Stuk 506 (1990-1991) - Nr.1, 6 May 1991.

Von Schomberg, R., 2012. Prospects for Technology Assessment in a Framework of Responsible Research and Innovation. In: Dusseldorp, M., Beecroft, R. (Eds.). Technikfolgen abschätzen lehren: Bildungspotenziale transdisziplinärer Methoden. Vs Verlag, Wiesbaden, pp. 39-61.

Winner, L., 1980. Do Artifacts Have Politics? Daedalus 109(1), 121-136.

Witte, E., Craeybeckx, J., Meynen, A., 1997. Politieke geschiedenis van België van 1830 tot heden. VUBPress, Brussels.

Wullweber, J., 2008. Nanotechnology - An Empty Signifier à venir? A Delineation of a Techno-socioeconomical Innovation Strategy. Science, Technology \& Innovation Studies 4(1), 27-45. 
Zeeuwts, P., 2004. Naar een Innovatiebeleid van de Derde Generatie. Samenleving en politiek 11(2), 3644. 
Table 1.

\begin{tabular}{|c|c|c|c|}
\hline & FGIP & SGIP & TGIP \\
\hline Time period & $80 s$ & $90 \mathrm{~s}$ & $?$ \\
\hline $\begin{array}{l}\text { View of } \\
\text { innovation } \\
\text { process }\end{array}$ & $\begin{array}{l}\text { Linear, from } \\
\text { research to } \\
\text { market }\end{array}$ & $\begin{array}{l}\text { Nonsequential } \\
\text { feedback loops }\end{array}$ & $\begin{array}{l}\text { Complex, nonlinear, } \\
\text { interactive, } \\
\text { nontechnical as well } \\
\text { as technical }\end{array}$ \\
\hline Main actors & $\begin{array}{l}\text { Scientists and } \\
\text { government }\end{array}$ & $\begin{array}{l}\text { As in FGIP plus } \\
\text { "nontechnical" } \\
\text { actors, e.g. 'social } \\
\text { partners'; } \\
\text { government as } \\
\text { innovation } \\
\text { mentor/enabler }\end{array}$ & $\begin{array}{l}\text { Actors from all policy } \\
\text { domains and all } \\
\text { relevant } \\
\text { stakeholders; } \\
\text { includes social } \\
\text { scientists and lay } \\
\text { publics }\end{array}$ \\
\hline $\begin{array}{l}\text { Types of } \\
\text { relations } \\
\text { among agents }\end{array}$ & $\begin{array}{l}\text { Vertical, } \\
\text { hierarchical }\end{array}$ & $\begin{array}{l}\text { Networked } \\
\text { ("horizontal") }\end{array}$ & $\begin{array}{l}\text { Integrated, } \\
\text { cooperative }\end{array}$ \\
\hline $\begin{array}{l}\text { Key concepts } \\
\text { and } \\
\text { metaphors }\end{array}$ & $\begin{array}{l}\text { Picking winners, } \\
\text { technology push }\end{array}$ & $\begin{array}{l}\text { Systems, clusters, } \\
\text { networks, bottom } \\
\text { up }\end{array}$ & $\begin{array}{l}\text { Interaction, learning, } \\
\text { knowledge-based } \\
\text { economy }\end{array}$ \\
\hline $\begin{array}{l}\text { Main } \\
\text { emphasis }\end{array}$ & $\begin{array}{l}\text { Science and } \\
\text { technology }\end{array}$ & $\begin{array}{l}\text { Innovation systems } \\
\text { and networks }\end{array}$ & $\begin{array}{l}\text { Knowledge, } \\
\text { collaboration, and } \\
\text { process }\end{array}$ \\
\hline
\end{tabular}

\footnotetext{
${ }^{1}$ It should be noted that these two FGIP concepts were not prominent in the eighties, but arose in later years.
} 
Figure 1.

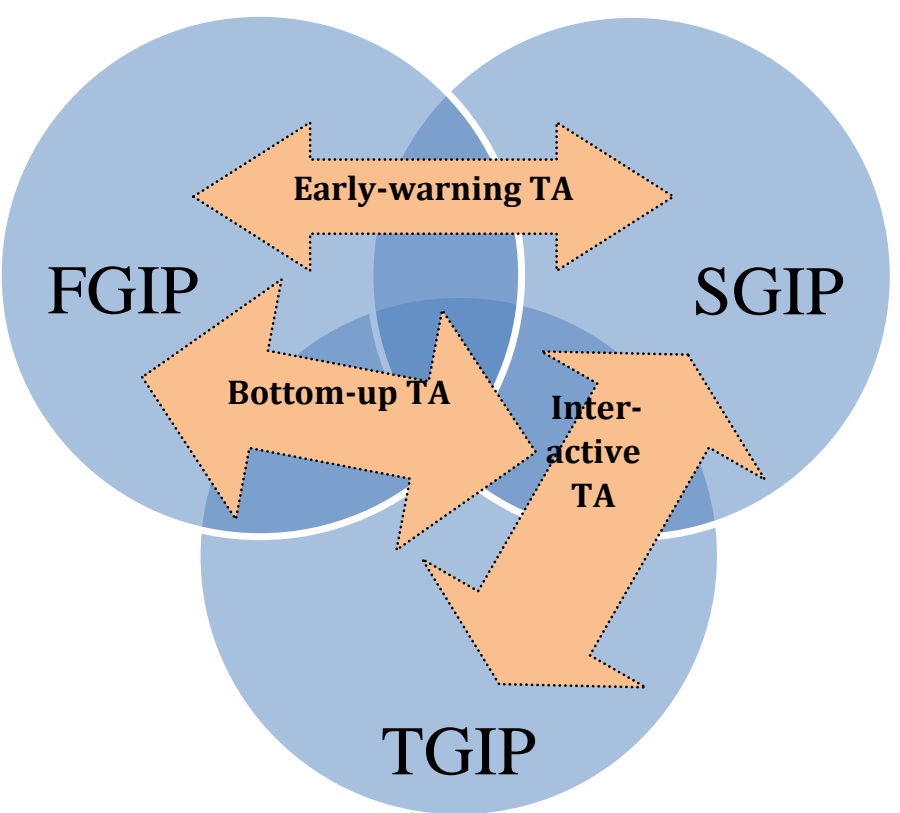

